\title{
Domestic Violence Subjected to Different Patterns of Cultural Marriage
}

\author{
Nazanin Boujarian', Mohd Tajudin Ninggal'1, Ssekamanya Siraje Abdallah ${ }^{2}$, \\ Masoud Noroozi ${ }^{3}$ \\ ${ }^{1}$ Faculty of Education, Universiti Teknologi Malaysia, Johor, Malaysia \\ ${ }^{2}$ Kulliyyah of Education, International Islamic University, Kuala Lumpur, Malaysia \\ ${ }^{3}$ University of Tehran Research Institute, Tehran, Iran \\ Email: n.boujarian@gmail.com
}

Received 26 March 2016; accepted 17 May 2016; published 20 May 2016

Copyright (C) 2016 by authors and Scientific Research Publishing Inc.

This work is licensed under the Creative Commons Attribution International License (CC BY). http://creativecommons.org/licenses/by/4.0/

(c) (i) Open Access

\begin{abstract}
Violence against women and girls and its legal, social, psychological and related issues are not a new topic in social science. However, it has attracted a significant amount of attention from many researchers and still needs further investigation. Among different sources provoking violence against females such as gender inequality, insufficient protective legal systems, cultural pressure and etc., different marital patterns have been reported by the informants of this research. Child marriage, consanguineous marriage and unregistered/white marriage put girls and women in a vulnerable position. For example, under the pressure of abusive behavior in family, females escape from patriarchal family, leave their city/country and live as a refugee. In more severe cases, they attempt suicide under the pressure of pain and suffering. In comparison with developed countries where the human rights of the female are well-established and such marital patterns are not seen, these types of martial patterns are reported in patriarchal societies. Therefore, this study introduces these patterns and describes their effects on provoking the domestic violence. Through interview sessions with victims of domestic violence, a qualitative methodology was used to gain in-depth information. To avoid or reduce the financial, emotional and physical costs of domestic violence, it is necessary that counselors, health care provider systems, society and authorities prioritize prevention methods and intervention programs to improve the cultural level of the society and to encourage people toward developing a violence-free society.
\end{abstract}

\section{Keywords}

Psychology, Counseling, Domestic Violence, Child Marriage, White Marriage 


\section{Introduction}

During past two decades, modernity and globalization in Middle East and African countries have brought big changes in women's life in terms of accessing to higher level of education, increasing the financial opportunities for females, improving the relationship between the generations within a family, modifying the marriage and divorce laws and etc. However, these changes have not equally happened in all of the Middle East countries especially in terms of marriage features. Even within one country, women and girls do not equally access to their rights in different regions/provinces [1]. Despite of the modernization, some marriage customs resisted against the modernity and its following changes. These marriage patterns are mainly categorized as Consanguineous Marriage, Child Marriage and Stop-Blooding Marriage in Persian society. On the other hand, White Marriage or unrecorded marriage has been developed recently with a rapid increasing rate in Persian society which is introduced as cultural invasion and condemned strictly by government and religious officials.

In this paper, the researchers review the percentage, definitions, consequences and the effect of these cultural marriage patterns in provoking domestic violence in Persian society. The domestic violence against females is investigated and the effective themes regarding different marital patterns intensifying the domestic violence are introduced. Although there are many cultural, financial, psychological, social and religious factors enhancing the violence against women which have been already considered by other researchers, in this study we focus on an important and less discussed issue regarding as marriage in Persian society (Iranians and Afghans) and its effects in provoking domestic violence. Four different patterns are discussed mainly as consanguineous marriage, child marriage, Stop-Blooding bride and white marriage. Through conducting interview sessions with Persian refugees and asylum seekers in Malaysia, the interview data were analyzed based on a qualitative method, and their main reasons for immigration to escape from violence were sought. This study introduces the necessity to improve the cultural level of the society and have a new modifying glance on the traditional features of culture.

\section{Background}

In this section, some definitions are introduced about different topics discussed in this paper. Domestic violence is represented and its different sources are introduced shortly. Also, four different patterns regarding various cultural marriage customs are described and discussed mainly. The definitions, consequences and the effect of these cultural marriage patterns in provoking domestic violence are considered.

\subsection{Domestic Violence}

Violence against women is a serious threat to health and right of women [2]. Domestic violence is one of the common types of violence that usually happen by women's partner [3]. Investigating this concept and developing the preventive methods have attracted great attention of many researchers in social science and related fields during recent decades [4]. According to the Department of Justice of the United States, domestic violence is defined as a pattern of abusive behavior that used to take power, control or authority over another intimate partner. The definition divided domestic violence to physical, sexual emotional, economic domestic violence can be physical, sexual, emotional, economic, or psychological actions or threats of actions that influence another person. This includes any behaviors that intimidate, manipulate, humiliate, isolate, frighten, terrorize, coerce, threaten, blame, hurt, injure, or wound someone [5].

To have a complete understanding of domestic violence in a society, it is necessary to identify different factors and conditions result in domestic violence. Among various sources provoking the domestic violence, one may refer to cultural pressure, gender inequality, insufficient legal and protective system, lack of financial support and incomes, social and religious factors, marriage patterns, etc. [6]. The domestic violence imposed by the partner of the woman tortures her mentally, verbally, physically and sexually. Under these pressures, females try to apply for a divorce case (if they are permitted) or leave their home and escape from that suffering environment. In many cases, they even attempt suicide to get free from pain of living in an abusive environment.

In a patriarchal structured society like Persian (Iranian and Afghan), domestic violence against female is an extensive phenomena. The UN General Assembly secretary in 2015, Ahmad Shahid reported 66 percent of Iranian women have experienced domestic violence and the result of the study shows that even during pregnancy, 14.1 percent of women was abused by their partners [7]. The prevalence of domestic violence in Persian society is high compare with developed countries where the legal systems have established to support the women's right strictly. In Persian society, a girl needs the permission of her father to get married officially, women have no 
right to travel or work without her partner's permission, the custody of their children is given to father as the legal guardian of the children legally and the female cannot apply for a divorce. Such conditions provide the possibility of provoking an abusive relationship in which wife has to obey her partner.

\subsection{Consanguineous Marriage}

One of the common marriage styles in south-west Asia is consanguineous marriage [8]. Demographic, cultural, social and religious factors are important predictors for prevalence of consanguineous in a population [9]-[13]. Consanguineous marriage generally refers to the marriage between persons with at least one common ancestor. Especially, it describes the marriages between individuals related as second cousins or closer. The most commonly form of consanguineous marriage is found between first cousins [9] [14]. The prevalence of relative marriage in Europe and USA are very low, but this kind of marriage is one of the common marriage styles in Middle East, central, south and west of Asia [14]. Consanguineous marriage also has an ancient history in Persian society even before 1979 Islamic revolution of Iran and it was existed in Iranian mythological literature [15]. It seems that religion is not the only factor that encourages the consanguineous marriage in Persian society; and it is very well acceptable by culture and local custom of Persians [16]. The well-known Iranian proverb says that "The first cousin's marriage contract was recorded in the heaven".

A national research project was conducted in Iran in 2001 to fill the gap of insufficient data regarding the prevalence of the consanguineous marriage in Persian society. The results of the research showed that there was no decline on the number of consanguineous marriage compared with previous statistic. Among more than 306,000 couples participating in the study, which was equivalent to $2.3 \%$ of all the families in the country form different ethnicities, the statistical mean of the consanguineous marriage was $38.6 \%$ ranging from $15.9 \%$ in northern provinces to $47.0 \%$ in eastern provinces [8].

Another study has been conducted in Afghanistan and data collections were included more than 7100 couples from Pashtuns, Tajiks, Hazaras, Turkmens and Uzbeks ethnicities. The statistical mean of the consanguineous marriage was reported $46.2 \%$ in the country, ranging from $38.2 \%$ to $51.2 \%$ in different provinces. The results of this study also show the prevalence of consanguineous marriage in Afghanistan is very high [17].

The main disadvantage of the consanguineous marriage is related to the reproduction. From genetic perspective, children of the consanguineous marriage are in a higher risk of major congenital malformation, infant mortality, being malformed or handicapped and autosomal recessive diseases [8]. On the other hand, this class of marriage sometimes categorized as forced marriage or arranged marriage extensively discussed in literature [18]-[20]. Both sides, girl and boy get forced to marry with each other to satisfy their parents and their family members and to follow their traditional custom. These types of marriage bring more problems in their future life as love affairs (i.e. sexual relationship, romantic friendship, or passionate attachment by others unbeknownst to the spouse).

\subsection{Child Marriage}

According to UNICEF, Child marriage is defined as a formal or informal marriage for boys and girls under age 18. It is widespread and can lead to disadvantage and deprivation along the life time, although girls are disproportionately the most affected [21]. Although in many countries, marriage under 18 is prohibited by law, but in some societies it is allowed under parental consent or under special circumstances (such as shotgun-wedding or cultural customs). Child marriage brings many problems especially for girls as early pregnancy, early motherhood, besides mental and health issues [22].

According to the International Convention on the Right of the Child, Article 1, every one under 18 is considered as a minor and they are not able to make informed decision included marriage due to not having a clear perspective about the nature and the consequences of these kinds of acts [23], unless the laws of a particular country set the legal age for adulthood younger. The Committee on the Rights of the Child has encouraged States to review the age of majority if it is set below 18, and to increase the level of protection for all children under 18 [24]. In comparison, based on the article 1041 of Iranian's law, the age of marriage for girls is 13 and for boys is 15 years old. However, child's guardians have the authority to request a court for their child marriage even earlier than mentioned ages.

Child marriage is also practicing in Persian society. Based on a report in 2013, brides of 53\% of marriages in this year were under 18 years old and 21\% of them were under 15 years old in Afghanistan [25]. According to 
the National Organization for Civil Registration Statistics of Iran [26], among more than 800,000 registered marriages per year, almost 35,000 cases involve girls below 15 years of age. The most recent reports indicate that within the period between 2007 and 2011, the number of child marriages rose from 33,383 to 39,831 [27]. Also it is shown that more than 420,000 girls under the age of 15 and 485,000 boys under the age of 20 got married between 2004 and 2014 [28].

Consequences of child marriage have very long lasting effects on entire life of children particularly girls [21] [29]. These consequences affect different areas of girl's health, education, legal rights, social interaction, marital relationship and also these effects influence even on their offspring's life. In terms of health conditions, these girls are in higher risks of early pregnancy, complications from pregnancy, sexually transmitted diseases, cervical cancer and malaria [30]. The risk of death during childbirth among the pregnant girl in $15 \mathrm{~s}$ is two times higher than pregnant women in $20 \mathrm{~s}$. Having an underweight baby or infant mortality is more common in these mothers. Their babies are in higher risk of weak immune systems or malnutrition [31].

Child marriage imposes higher level of stress on children regarding early pregnancy, playing parenting role without having enough parenting skills and etc. So it is considered as a threat to the health and well-being of children and causes depression [22]. Child marriage increases the risk of domestic violence, child sexual abuse and marital rape as well [21]. All mentioned challenges have very negative effects on girl, her social interactions, her marital relationships with the spouse and usually ends up with domestic violence. The husbands usually is very elder than the girl and therefore, teenage girl may face with sever domestic violence compared with the other teenagers [32]. In addition, married girls with a low level of education are in a greater risk of social isolation and domestic violence compared with more educated ones [33].

Based on marriage law in Persian society, husband has the right to decide about the place of residency. So, place transition after marriage leads to the loss of the girls' social support system (from their original family) and brings more isolation on life of young married girls among in-law family members [20] [22]. In the case that the age difference is high, the age gap between married couple in this marriage pattern and expectations of in-law family cause serious mental health problems for these girls and put them in a higher risk of being as a victims of domestic violence [34]. Furthermore, Lack of knowledge about marital life, immaturity for getting involved in sexual relationships and being physically and mentally unprepared for marital life and its following duties and roles put young married girls in a vulnerable situation of domestic violence [35].

\subsection{Stop-Blooding Marriage}

One of the other marriage patterns that are practicing in Persian society is called Stop-Blooding marriage (known as Khoon-Bas). This marriage custom is recognized in some ethnicities of Persian society like Lor, Kurd, Balouch, Arab, Bakhtiari, etc. and almost in all of the 34 provinces of Afghanistan. According to this custom, if the father, brother or any close relatives of a girl kills a guy from another family or tribe, for preventing of more fights and conflicts between two families or tribes, the chief of tribe or village order to the guilty family to give an underage girl to marry with murder's family brother or relatives [36]. Most of these grooms have already wives and children and the bride does not have any right. No wedding ceremony will be performed in a case of Stop-Blooding marriage. They do not have any dowry. They are like a servant in the murder's family and if the murder's family decide to return them to origin family, it is completely acceptable for both parties. The bride is quietly escorted to her new home, where she is often abused by her vengeance-seeking in-laws [37]. The Persian community punishes the Stop-Blooding bride with a slavery life and imposes her the violence for whole of her life, for the crime that she never committed. Stop-Blooding marriage is known as a marriage custom that violates the right of girl's decision making in choosing her partner and living conditions and leads to domestic violence as well [6].

\subsection{White Marriage (Marriage Blanc)}

Cultural and legal system of Persian society put females in unfair situations compare with males. Modernity and higher education motivated Persian girls to break these unfair cultural and legal rules and pursue their dreams to have equal rights with men in their society. The concept of white marriage is one of the unique products of modernity to fight with unfair conditions of marriage contract in patriarchal Persian society. In this pattern, the marriage is not registered officially and legally. In other words, the females accept to undergo an unregistered marital status to escape the ties and obligations that they are asked to follow upon signing the marriage contract, 
and to save their freedom, the divorced right and so on. They believe that when they have their own job, and they earn their living and they are independent, nobody should dare to ask them about marriage [38]. White marriage is not acceptable by Persian government, but is increasing among young generation underground [38].

Not only young educated Persian girls, but also some widow and divorced women are practicing this marital style recently. The life for women even after divorce is not an easy one. Challenges of finding a place to live, a financial support and being safe from sexual harassment force some divorced women to overcome with these suffering by choosing the white marriage pattern as their marital life style.

Despite cohabitation is illegal in Islamic countries and both parties are sentenced to lash or death, but the abovementioned group of females practice the white marriage style for different reasons, including reducing the high expenses of marriage ceremony and marital life, avoiding cultural features of marriage, twisting unfair and unequal laws against women, knowing their partner before going for an official commitment and etc. [38]. Although, by taking an unregistered marital status, women can obtain more freedom in their marital life, but they commit an illegal action and therefore, they lose any protection of the society and the legal system. They are usually rejected by their original family and so they have to live far from them in loneliness. The society does not support these groups looking at them as sinners or prostitutes, so they have to choose a hidden life with their partner. They cannot get pregnant, because the newborn does not receive any right, and no identification document issued by the official centers. They have no right to claim a lawsuit against their partner, because they are already considered as a guilty. Lacking the support of family, society and legal system make them ready to undergo an abusive relationship. Usually they have to accept these suffering conditions to have a room for living, have a meal for eating, and have a shelter for being safe from other men's harassments [6].

\section{Problem Definition and Analysis Approach}

In this section, the main objective of the research is introduced and the analysis approach is described shortly. The materials are represented as follow:

\subsection{Problem Statement}

This study explores the phenomenology of domestic violence among Persian women refugees residing in Malaysia. The aim of this study is to capture the essence of the informants' experiences and their view toward violence. Especially, it focuses on the important factors provoking the migration rate due to domestic violence regarding different marriage patterns. Domestic violence has a wide range of effects on individual, their family members and their society in terms of social and financial costs. Abuse recovery even by receiving professional and emotional support is very difficult and ideologically requires to match with the needs of victims.

Considering different reasons of immigration between the women (especially the refugees and asylum seekers), it was observed that to escape from patriarchal structure of their society is one of the main factors. Due to domestic violence resulted by cultural factors such as legal and cultural pressures or different marriage pattern, the victim has to undergo any abusive relationship verbally, physically, sexually and emotionally or leave her family/city/country. In other words, the women had to leave their family, get separated, leave their original country and accept all the upcoming risks, stresses and fears just to run away the atmosphere of their traditional based society and its mental and physical pressures; hoping to get some relief to breathe freely in a new atmosphere. The importance of this topic encouraged the researcher to consider the problem sources for this group of women (i.e. immigrant especially refugees).

Among different sources of domestic violence, different marriage patterns have not been studied completely by other researchers. This issue has been especially reported in Persian society with a patriarchal structure (Iranian and Afghan). Due to these marriage patterns, the girls have to get marry someone usually much elder with a big age gap, or they are forced to undergo consanguineous marriage with relatives to satisfy the traditional customs. On the other hand, women have to undergo the unregistered/illegally white marriage just to gain a shelter and daily meal for themselves or their kids, because it is hard to find the opportunity to get a job and to earn money for a divorced woman. In comparison with other developed countries where the rights of the women are well established and controlled by the official agencies, such unregistered relations in Persian society is considered as adultery and no rights is considered for the women and her offspring. The lack of social and legal support for women in such a society spreads the prevalence of abusive behavior against unsupported females. Therefore, this study is focused on these different marriage patterns supported culturally in Persian society, their 
contributions in spreading domestic violence and its following issues.

\subsection{Methodology}

Qualitative methodology, in particular a phenomenological approach was used for this study. The interview questions were semi structure questions included five main questions, each one was followed by some subquestions. The concept of the interview focuses on domestic violence experiences of Persian women refugees and challenges that they already encountered. Materials such as study setting and participant's characteristics involved in these researches beside the sampling phase and data collection process are described as follow.

The setting of this study was included refugee clinics located in Kuala Lumpur, the capital city of Malaysia. Researcher worked as a volunteer for three years in UNHCR to have some observations in refugee field and diagnoses one the most challenging issues that Persian refugee women are dealing with. Later on, for finding suitable informants, more than 60 individual sessions were conducted at those clinics. Finally, 15 informants took part in this study including 7 divorced women, 3 widow women and 5 women migrated with their children to Malaysia without getting divorced. All of informants were Persian women (Iranian or Afghan) who were residence of Iran or Afghanistan before immigration and currently as a refugee/asylum seeker in Malaysia.

Purposeful sampling was used as a sampling method. Fifteen Persian women accepted to take part in this study. Fifty five individual, face to face interviews were conducted at clinics. Researcher is a native Persian speaker and all interviews conducted in the Persian language and then translated into English for the purpose of expert checking. Interviews were recorded and transcribed verbatim to ensure accuracy of the data. Because of the sensitivity of the concept, the research did not start the interview with direct questions. Therefore, at the beginning of each interview, informants were asked to explain a history of their life and their immigration process. After they felt more comfortable, at the second session more deep and direct questions were asked.

\subsection{Data Analysis}

Data analysis started with transcribing the recorded interviews and thematic analysis was used for qualitative analysis of the data. The most common method of analyzing the data in qualitative research is thematic analysis [39]. The emphasis of this method is on finding, testing and recording the themes within the data [40]. Themes are important in describing the phenomenon and are related to specific research questions [41]. Six phases of thematic analysis are included: becoming familiar with the data, generating initial codes, searching for themes, reviewing themes, defining and naming themes, producing the report [41]. In addition, field notes were made on each interview regarding mannerisms, body language of any sort and general comments regarding the interviews.

\section{Results}

In this study, different patterns of marriage in Persian culture are considered. Based on the perceptions and the experiences of Persian refugee women, the sources of domestic violence provoked due to marriage styles are considered and the original factors encouraging/forcing women to migrate are studied. Four major themes are presented and the following domestic violence were identified in data analyzing process. At first, some observations from the analyzed data are presented and then some discussions are concluded.

\subsection{Observations}

In patriarchal societies, the right of women for decision making in their life has been limited in many ways which is classified under violence category. For example, choosing a partner for marital life is one of the issues that girls have to obey their father/family decisions. It can be happened even if the girl is a teenager and so she is not matured enough to be ready to accept the responsibilities of a wife/mother. Most of the informants of this study have experienced arranged marriage. Two following quotations are sample cases represented by domestic violence victims who experienced consanguineous marriage in Persian patriarchal society.

"I was born in Iran, but my nationality is an Afghan. My parents were illiterate. I was a very good student in the second year of my secondary school. I had big dreams for my future, enjoying new things to learn. One day, when I came back home from the school, I saw my uncle and his family. They were living in Afghanistan. When I was born, my father promised to give me to my cousin. He was 10 years older than me. I 
had seen him just twice before in my life. I could not oppose their decision. We needed to keep my father's promise. I married him and moved with him to Afghanistan. The social life of women in Afghanistan was totally different from Iran. Later on, when he started abusing me, I found he also was not interested on me. Actually, he was in love with the daughter of their neighbor. But he also could not oppose the old promise." $(X 7,45)$

"When I was teenager, I would like to experience new things. I would like to spend more time with my classmates instead of going to religious ceremonies with my mom. My family was very religious and whatever I was curious to know or to do, they did not give me a permission to do. I was not look like my sibling to take my parent's orders without reasoning. They put a lot of restrictions on me for my behaviors to tie me up. I was curious to talk with other boys for fun, without any aim to do any immoral behavior. But my parents did not have any understanding of my needs and afraid that I have some affair before marriage and dishonor them, so they wanted to prevent this incident and forced me to get marry my cousin whom I grew up with him. He was as my brother to me. After several times of ignoring by him during my marital life, I found that he was not interested in me. He just married me just because he thought that owing to my father as his fosterer, he wanted to show his appreciation to my father by marring me, so he ruined my life. I had to stay there and live under verbal, mental and physical harassment or to escape from my country." (X5, 39)

Child marriage is still practicing in Persian society. The child under 18 years old are not physically and emotionally matured enough to start their marital life and take the huge responsibilities of being a housewife or a mother. Their Immaturity cause lots of conflicts with their family in-law and their husbands who usually are much more elder that them. Poverty, illiteracy, patriarchal cultural pressure and similar issues can be motivators of practicing this customs in Persian society. These children do not have enough life skills or parenting skills and so, there are no supportive sources for them. They cannot make any complain of their guardians, they are underage and do not have any legal right. After marriage, their origin family advises them to be patient and return back to husband's house. They cannot ask help from other people to avoid accusing of having an affair with others and they have to accept the abusive relationship in their husband's house. As a sample case, it can be referred to the experience of an informant as she narrated:

"My father was passed away when I was just two years old. My mom married a guy and migrated to another country and my uncle took my guardianship. I studied religious lessons for two years and our religious teacher said that is sufficient for a girl. I was 8 years old, when my uncle forced me to work in different stores as a worker. I was 11 when my uncle's wife asked her spouse to give me to her brother who was 55 years old. He had a wife and children. I did not know any things about the marriage and I suffered a lot till the time I just fled my country. If I wanted to stay there anymore, they may find and kill me." (X13, 90)

Stop-Blooding birde (Khoon Bas) is a woman without any right and has to marry with murder's family. There is no choice and option for her. The bride does not receive any dowry or any respect. Her role is just to terminate the conflict by sacrificing her life. She is just a servant in murder's family house without any right of complaining about her condition. After the engagement, the woman does not belong to any family or tribe even her origin family. This custom makes the woman vulnerable for blame and abuse from murder's family. Even if her husband passes away, she is not allowed to return back to her origin family. She should serve murder's family for her entire life. She is just as belongings of the murder's family. The risk of domestic violence is very high among these Stop-Blooding brides.

"I was 11 years old when I became the Stop-Blooding bride (Khoon-Bas). My brother killed a guy and I had to get married to the victim's brother to save my brother's life. From the first day of my marriage, I remember I got beaten very badly by my ex-husband. He always mentioned to me that: "I do not want to see you around and whenever I see you, you remind me my brother's death". I did not have any other option; I had to tolerate whatever he did to me, because I was a Stop-Blooding bride without any right. In order to save my life, I had to leave my original country and living here as a refugee." (Women X3, 18)

Divorced, widow or unmarried women face with variety of challenges and problems. The majority of these challenges are caused by the perspective and perceptions of Persian society toward these women. On the other 
hand, they are really in need of finding a suitable career to support themselves, but there is not a secure and safe work environment for them. The Persian society has very negative impression about these women and looks at them as women that are ready to have an affair or sexual relationships in times of request. Even after dead of an abusive husband or ending a violent relationship, there are no facilities to empower them to start an independent life. So, there are just a few options for them. White marriage is a way helps them to hide themselves behind a partner without having any legal or social support. The occurrence of domestic violence is common among this group. As a sample case, it can be referred to the experience of two informants as follow about unregistered marriage style:

\begin{abstract}
"After my abusive husband passed away, the life still was not an easy one for me. He isolated me inside the house for several years and I did not have any social connection or skills. My parents also were passed away and there was nobody to help me financially or emotionally. My saving almost was over, and getting married quickly after my husband death was not acceptable in society. I met a guy and he was a bus driver, he was willing to rent a room for me and my daughter and expected me to live unofficially with him. He did not want anybody specially his wife and his children know about our relationship. He claimed that his wife is not caring person. There were not many options for me. I should choose to serve him instead of having a shelter or sleep at the park as a homeless one. He was a drug addicted and had many abusive behaviors, whenever I complained him about his behavior, he asked me to leave his place." $(X 8,12)$

"I got divorced from my ex-husband. I had a son and my father who did not agree with my first marriage, did not give me any hand after my separation. I was very young with a two years old son. I was looking for a part-time job. But with having a baby, finding a job was not easy. I was very helpless. My saving also was almost over; my friend suggested me to start living with a young guy as his partner and instead of doing house duty and satisfying his needs, he could share his house with us. It was not easy to live with a young guy, but I did not have any better options." $(X 3,34)$
\end{abstract}

\title{
4.2. Discussion
}

The abovementioned observations provide some interesting points in investigating different marital patterns in Persian society provoking the domestic violence against females. Here, some remarks are discussed briefly about the consanguineous marriage, child marriage, stop-blooding marriage and white marriage.

Cultural marital customs such as consanguineous marriage and stop-blooding bride especially in rural and less developed regions forces girls to have unwilling marriage. The girls have to obey the customs and undergo any abusive relationship from in-law family and the husband. Almost all of the informants did not receive any kind of support from their family of origin when seeking support. Some of the cases mentioned that their family members advised them to get pregnant, undergo any condition of the in-law family and just focus on satisfying their husbands. They even started to blame their daughter for being rude with her husband. The cases did not have any options; whenever the violence happened and they try to seek help from their family of origins, they were forced to return to their husband and to stay with him under any conditions.

Child marriage is legal in Persian society and based on Sharia law, girls at the age of 13 are considered as adults to legally marry [6]. One of the main reasons leading the child marriage is the misunderstanding of the families about their supportive roles that they may have for their daughters. By forcing the girl to undergo a marital status, they suppose that her welfare for all of her future life is guaranteed. The resistance of the girl in following the father's decision is attributed to her crudity and is usually suppressed. They assume that early marriage is a protective tool against sexual relationship of female before marriage or it prevents rape incidents of young girls to avoid being dishonored. Ignoring women's right to choose their partner, besides committing the basic aspect of violence leads to consequences for women in their future life with their partner intensifying the domestic violence and abusive relationship.

Modernity has encountered traditional Persian society with new issues in social life such as unregistered/ white marriage, and the problems that single women deal with in society such as difficulties in finding a room or a job for living, provoke them to undergo unregistered marriage. These factors provoke the sources of domestic violence by decreasing the level of independence of women in society and forcing them to undergo any abusive relationship. Therefore, it is necessary to develop the job positions for women and to defeat with gender inequalities in all of its aspects and also develop attempts to change the viewpoint of society about single women. 
Almost for all of the informants of the study, their marriages could be categorized under one of the abovementioned cultural patterns. Their rights were violated by their guardian and also with their husbands after marriage in different areas. They did not have any right to choose their future partners. The reasons for theses cultural marriages rooted in poverty, respect to traditions and cultural norms, stop conflict with guardian, illiteracy and etc. Most of them were very younger than their husbands. They were very immature to start their marital life. Expectations of their husband and in-law family and their weakness to meet these expectations put them more vulnerable for domestic violence.

The study shows most of the informants did not receive any kind of professional or legal help in the time of their violent relationship. They went through the long process of legal separation as they have no right to apply for a divorce case. They have to abandon the children custody which was very frustrating and bothering for them. Few of them who could successfully divorced from abusive husband, also complained that there were not any bright futures for a divorced lady in society. They even faced with more social and personal challenges which forced them to enter an illegal relationship and re-experience the violence. Almost all of the informants sought asylum and refugees for ending up to all sufferings that they went through.

Culture, religious and legal systems of every society have significance effect on provoking or preventing of domestic violence. In this study, emphasis of the researchers was on importance of knowing the different patterns of cultural marriage in Persian society especially for counselors and humanitarian organizations who are aiming to provide multicultural service for refugees. Based on the results of this study almost all of different patterns of cultural marriages surprisingly were still practicing in different regions in Persian society. These results are consistent with some other earlier studies in Persian society that had shown the prevalence of these marital patterns are high [8] [12].

In order to make living conditions much better for females to breath in a violence-free society, some suggestions may be considered. Setting up some NGOs to help the victims, improving the supportive systems of the female's right, upgrading the legal system and considering protective tools may support women preventing them to undergo an abusive relationship. Propagating the appropriate educational program for both females and males is another important step changing people's religious and social cognition. The more educated people, the less rate of the violence appears in the society. It is necessary to train the society and to change the traditional features of culture according to the situations in which all the people in the society, especially girls and women live in a violence-free society. It is necessary that all the members of the society, both males and females, join the national movements to support any action against violence in any type to sanctified human values.

\section{Conclusion}

In a society with patriarchal structure, females encounter different problems due to their gender. Therefore, different violent relationships appear mainly targeting women as the victims. There are different sources including cultural, social and legal factors supporting the domestic violence against females. In this study, the importance of marriage patterns is considered on provoking violence. Four different patterns are introduced in which the girl/woman has to obey her traditional custom, her father's decision in getting married with someone else. In the case of child marriage, the partners are much elder than the girl and the marriage brings many mental and physical problems for immature girl. In some cases, the girl has to marry with a relative against her willing classified as consanguineous marriage. More recently, the women have to undergo unregistered marital status to find financial support. In this case, the woman is prohibited from all of her legal rights due to the religious laws of the government. All of these marital patterns increase the rate of domestic violence against females verbally, physically, sexually and mentally. In some cases, the women have to escape from their home, leave their family and seek a refugee position in another country. Some cases attempt suicide due to severe pressures. This paper highlights the effect of different marital patterns on provoking the domestic violence against females and to propose the society, the law makers, and all the humans to stand all together for making a violence free society all over the world.

\section{Acknowledgements}

This paper was extracted from a Ph.D. thesis in Guidance and Counseling at the Faculty of Education at the University Technology Malaysia (UTM). Authors would like to acknowledge the kind support of Malaysian Social Research Institute (MSRI) for providing the possibility of data collection, conducting the research and 
holding the sessions with applicants. The researcher also would like to appreciate all the participants who shared their valuable experiences with the researcher.

\section{Ethical Consideration}

The study was approved by the Research Ethics Committee of the Faculty of Education at the University Technology Malaysia (UTM). Individual briefing sessions were hold with all Persian clients of clinics and informed written consent were signed by volunteer informants. The participation of applicants in this research was completely voluntarily and could be withdrawn anytime during the study. The demographic data notes and the interview transcripts collected by the researcher were kept strictly confidential. The informants were assigned with alias names for the purpose of anonymity though transcription and written documentation. At the end of the study, all of the recordings and transcription were destroyed.

\section{Declaration of Conflicting Interests}

The authors(s) declared no potential conflicts of interest with respect to the research, authorship, and/or publication of this article.

\section{Funding}

The researcher(s) received no financial support for the research, and/or publication of this article. All the fees including the research charges and publication costs were paid by personal funds of the researchers.

\section{References}

[1] Tremayne, S. (2006) Modernity and Early Marriage in Iran: A View from Within. Journal of Middle East Women's Studies, 2, 65-94. https://unama.unmissions.org/sites/default/files/harmful_traditional_practices_english.pdf-94 http://dx.doi.org/10.2979/mew.2006.2.1.65

[2] Salam, A., Alim, A. and Noguchi, T. (2006) Spousal Abuse against Women and Its Consequences on Reproductive Health: A Study in the Urban Slums in Bangladesh. Maternal Child Health, 10, 83-94. http://dx.doi.org/10.1007/s10995-005-0030-6

[3] Shipway, L. (2004) Domestic Violence: A Handbook for Health Care Professionals. Routledge Taylor \& Francis Group, London.

[4] Krug, E.G., Mercy, J.A., Dahlberg, L.L. and Zwi, A.B. (2002) The World Report on Violence and Health. The Lancet, 360, 1083-1088. http://dx.doi.org/10.1016/S0140-6736(02)11133-0

[5] Department of Justice of the United States (2015) What Is Domestic Violence? https://www.justice.gov/ovw/domestic-violence\#dv

[6] Boujarian, N., Ningal, M.T. and Ssekamanya, S.A. (2016) Domestic Violence Subjected to Legal and Cultural Pressure. International Journal of Education and Psychological Research, 5, 51022. (In Press)

[7] Shahid, A. (2015) Situation of Human Rights in the Islamic Republic of Iran: Report of the Secretary-General, UN General Assembly. http://www.ohchr.org/EN/Countries/AsiaRegion/Pages/IRIndex.aspx

[8] Saadat, M., Ansari-Lari, M. and Farhud, D.D. (2004) Short Report Consanguineous Marriage in Iran. Annals of Human Biology, 31, 263-269. http://dx.doi.org/10.1080/03014460310001652211

[9] Bittles, A.H. (1994) the Role and Significance of Consanguinity as a Demographic Variable. Population and Development Review, 20, 561-584. http://dx.doi.org/10.2307/2137601

[10] Bener, A., Abdulrazzaq, Y.M., Al-gazali, L.I., Micallef, R., Al-khayat, A.I. and Gaber, T. (1996) Consanguinity and Associated Socio-Demographic Factors in the United Arab Emirates. Human Heredity, 46, 256-264. http://dx.doi.org/10.1159/000154362

[11] Hussain, R. (1999) Community Perceptions of Reasons for Preference for Consanguineous Marriages in Pakistan. Journal of Biosocial Science, 31, 449-461. http://dx.doi.org/10.1017/S0021932099004496

[12] Varela, T.A., Ainsua, R.L. and Farina, J. (2001) Evolution of Consanguinity in the Bishopric of Lugo (Spain) from 1900 to 1997. Annals of Human Biology, 28, 575-588. http://dx.doi.org/10.1080/03014460110047955

[13] Jurdi, R. and Saxena, P.C. (2003) the Prevalence and Correlates of Consanguineous Marriages in Yemen: Similarities and Contrasts with Other Arab Countries. Journal of Biosocial Science, 35, 1-13.

http://dx.doi.org/10.1017/S0021932003000014 
[14] Bittles, A.H. (2001) Consanguinity and Its Relevance to Clinical Genetics. Clinical Genetics, 60, 89-98. http://dx.doi.org/10.1034/j.1399-0004.2001.600201.x

[15] Saadat, M. (2000) Consanguinity in Iranian Mythological Literature of Iran. Proceedings of First Congress on Human Genetics, Shahre-Kurd University of Medical Sciences Press, Shahrekord, 72-79.

[16] Akrami, S. M. and Osati, Z. (2007) Is Consanguineous Marriage Religiously Encouraged? Islamic and Iranian Considerations. Journal of Biosocial Science, 39, 313-316. http://dx.doi.org/10.1017/S0021932006001684

[17] Saify, Kh. and Saadat, M. (2012) Consanguineous Marriages in Afghanistan. Journal of Biosocial Science, $44,73-81$. http://dx.doi.org/10.1017/S0021932011000253

[18] Bhuia, M.R., Rahman, Kh., Alam, Kh., Smrity, L.A. and Hossain, Md.Ka. (2015) Forced Marriage in Bangladesh: A Quantitative Study to Identify Key Factors. Open Journal of Applied Sciences, 5, 450-459. http://dx.doi.org/10.4236/ojapps.2015.58045

[19] Phillips, A. and Dustin, M. (2004) UK Initiatives on Forced Marriage: Regulation, Dialogue and Exit. Political Studies, 52, 531-551. http://dx.doi.org/10.1111/j.1467-9248.2004.00494.x

[20] Boujarian, N., Ningal, M.T. and Ssekamanya, S.A. (2016) The Significance of Higher Order Thinking Skills in Domestic Violence Prevention Program. Proceeding of International Conference on Education and Higher Order Thinking Skills, Universiti Teknologi Malaysia, Johor Bahru. (In Press)

[21] UNICEF (2014) Child Marriage. http://www.unicef.org/protection/57929_58008.html

[22] Nour, N.M. (2009) Child Marriage: A Silent Health and Human Rights Issue. Reviews in Obstetrics and Gynecology, 2 , 51-56.

[23] Sudwind Organization (2014) Violations of Girls Rights in Iran, Child Marriage and FGM in I.R. of Iran.

[24] General Assembly Resolution (1989) Convention on the Rights of the Child. The Office of the United Nations High Commissioner for Human Rights (OHCHR). http://www.ohchr.org/en/professionalinterest/pages/crc.aspx

[25] Rabi, A. (2014) Cost of Inaction: Child and Adolescent Marriage in Nepal. UNICEF Nepal Working Paper Series.

[26] Statistical Centre of Iran (2016). (In Persian)

[27] Justice for Iran Institution (2013) Early and Forced Marriages in the Islamic Republic of Iran: A Brief Submitted to the Office of the High Commissioner for Women's Rights and Gender Section (WRGS), for the 26th Session of the Human Rights Council. London.

[28] Shahrvand Newspaper (2015) No 639. (In Persian)

[29] Hill, A. (2004) Revealed: The Child Brides Who Are Forced to Marry in Britain. The Guardian. http://www.theguardian.com/uk/2004/feb/22/ukcrime.gender

[30] Bunting, A. (2005) Stages of Development: Marriage of Girls and Teens as an International Human Rights Issue. Social and Legal Studies, 14, 17-38. http://dx.doi.org/10.1177/0964663905049524

[31] Blake, M. (2013) Yemeni Child Bride, Eight, Dies of Internal Injuries on First Night of Forced Marriage to Groom Five Times Her Age. Daily Mail. http://www.dailymail.co.uk/news/article-2415871/Yemeni-child-bride-8-dies-internal-injuries-night-forced-marriage-g room-40.html

[32] UNICEF (2005) Early Marriage: A Harmful Tradition Practice. http://www.unicef.org/publications/index 26024.html

[33] Lee-Rife, S., Malhotra, A., Warner, A. and McGonagle, G.A. (2012) What Works to Prevent Child Marriage: A Review of the Evidence. Studies in Family Planning, 43, 287-303. http://dx.doi.org/10.1111/j.1728-4465.2012.00327.X

[34] Rai, R.K., Singh, P.K., Singh, L. and Kumar, C. (2014) Individual Characteristics and Use of Maternal and Child Health Services by Adolescent Mothers in Niger. Maternal and Child Health Journal, 18, 592-603. http://dx.doi.org/10.1007/s10995-013-1276-z

[35] U.S. Department of State (2010) Targeting Girls in the Name of Tradition: Child Marriage. http://www.state.gov/s/gwi/rls/rem/2010/144989.htm

[36] UNAMA (2010) Harmful Traditional Practices and Implementation of the Law on Elimination of Violence against Women in Afghanistan. https://unama.unmissions.org/sites/default/files/harmful_traditional_practices_english.pdf

[37] Gandhara (2015) Rural Afghan Girls Continue To Fall Victim to “Baad” Marriages. http://gandhara.rferl.org/a/afghanistan-baad-marriages-rural-girls/27157104.html

[38] Los Angeles Times (2015) White Marriage: A Growing Trend for Young Couples in Iran. http://www.latimes.com/world/middleeast/la-fg-iran-white-marriage-20150529-story.html

[39] Guest, G., Macqueen, K. and Namey, E.E. (2011) Applied Thematic Analysis. SAGE Publications Inc., Thousand Oaks. 
[40] Braun, V. and Clarke, V. (2009) Using Thematic Analysis in Psychology. Qualitative Research in Psychology, 3, 77101. http://dx.doi.org/10.1191/1478088706qp063oa

[41] Daly, J., Kellehear, A. and Gliksman, M. (1998) The Public Health Researcher: A Methodological Guide. Oxford University Press, Melbourne, 611-618. 